\title{
Association Study Between Thermal Front Phenomena and Bali Sardinella Fishing Areas in Bali Strait
}

\author{
Argo Galih Suhadha ${ }^{*}$ \\ Remote Sensing Application Center (RSAC), Indonesian National Institute of Aeronautics and Space (LAPAN), \\ Indonesia .
}

\author{
Andi Ibrahim \\ Remote Sensing Application Center (RSAC), Indonesian National Institute of Aeronautics and Space (LAPAN), \\ Indonesia.
}

Received: $2020-02-03$ Accepted: 2020-07-13

Keywords: thermal front;

SST;

Bali Sardinella;

Fishing areas;

Bali Strait

Correspondent email: argo.galih@lapan.go.id

\begin{abstract}
Thermal front has been widely used as a parameter for determining fishing zones. This study aimed to determine the thermal front distribution and to analyze its association with the Bali Sardinella fishing zones in the Bali Strait. Thermal front generated using sea surface temperature (SST) from Aqua MODIS imagery. Meanwhile, the fishing point data of Bali Sardinella were collected to validate our analysis results. The data were analyzed into Spatio-temporal information. The main facts that stand out are that the thermal front was predominantly found in the peak of first (April) and second (September) transitional season, which was the peak season for the thermal front to occur in a year. The least of the thermal front occurred in the South-west monsoon. The linear relationship was found when the peak of thermal front occurrence compared to the number of catch yields. Based on matching distance analysis, the maximum distance used (twenty kilometres buffer) show 36 matching points from 101 data compared or at range $35.6 \%$. In conclusion, there is a linear relationship between the thermal front parameter and catch yield. It is still used to predict the fishing zone, even though the correlation is not significantly found.
\end{abstract}

\section{Introduction}

Generally, the front is a zone of transition between two air or water masses of different density and temperature and is associated with significant changes in the weather and ocean. The thermal front is a meeting area of two water mass that has different sea surface temperature characteristics. That affects the physical and biological conditions of waters. The meeting between the warm Java seawater mass and the cooler Indian Ocean water mass is an example of a potential thermal front area in Indonesian waters (Jatisworo \& Murdimanto, 2013; Podestá et al., 1993).

According to Robinson, (2006), the thermal front has a vital role in seawater productivity because the distribution brings together cold water with rich nutrients and warmer water which is the preference of fish but deficient of nutrients. Warm water temperatures and adequate nutrition will increase plankton productivity, and this increase will affect the rise in fish stocks in the area.

The thermal front study has been developed since the early 18th century where J. F. Cayula \& Cornillon (1992) developed an algorithm to detect the front using a histogram algorithm in a single image called single image with edge detection (SIED). Furthermore J.-F. Cayula \& Cornillon (1995) developed that algorithm for multi-image detection. In other cases, Ullman \& Cornillon (2000) evaluated the method with in situ observations where was the results showed the application of automated edge detection methods to long time series of AVHRR images provide acceptably accurate statistics on front occurrence. In Indonesian seas, the algorithm by J. F. Cayula \& Cornillon (1992) has been implemented to detect thermal front and operationally generate as the main parameter in Potential Fishing Ground (PFZ) product in LAPAN and Indonesian Institute for Marine Research and Observation (BROL) (Hamzah et al., 2016; Hanintyo et al., 2015; Jatisworo \& Murdimanto, 2013).

One of the important fisheries commodities and only found in Bali Strait waters is Bali Sardinella (Pet et al., 1997). Bali Sardinella classified as small pelagic fish which is a filter feeder fish whose primary food is phytoplankton and zooplankton (FAO, 2001). Bali Sardinella can be found in waters with sea surface temperature (SST) range in $25-26,5^{\circ}$ $\mathrm{C}$ and chlorophyll-a concentration of $0.25-0.65 \mathrm{mg} / \mathrm{m}^{3}$ (Susilo, 2015) so that Bali Sardinella expected to be predictable with the thermal front location.

Previously, Jatisworo \& Murdimanto (2013) have identified thermal front in Makassar Strait and Banda Sea where they found thermal front distribution using Single Image Edge Detection (SIED) method from J. F. Cayula \& Cornillon (1992) with $0,5^{\circ} \mathrm{C}$ as a threshold. Besides, Hamzah, Prayogo, \& Harsanugraha (2014) have applied the Single Image Edge Detection (SIED) method from J. F. Cayula \& 
Cornillon (1992) to detect thermal front in Java waters and find threshold values and histogram window sizes that can be applied in Indonesian waters that is $0.3^{\circ} \mathrm{C}$ dan $32 \times 32$ kernel. Podestá et al. (1993) in this research found swordfish CPUE association with distance to the nearest front, and significant associations were only found when CPUE was high with 50 fish per 1000 hooks. The results indicate that may the thermal front has an influence on the high CPUEs but is not the only one factor.

Based on previous research, RSAC LAPAN has produced potential fishing zones (PFZ) information daily in the Indonesian water area based thermal front as the main parameter. The thermal front detected using the SIED method with $0.5^{\circ} \mathrm{C}$ threshold and $3 \times 3$-pixel kernel. Although LAPAN's PFZ has operated since 1998, the validity level of PFZ identification based on thermal front information with fish catch areas in Indonesia waters cannot be known with certainty. To answer the validity level of the method used on LAPAN's PFZ, this research is conducted to find the association of thermal front parameters to the Bali Sardinella fishing area in the Bali Strait.

\section{The Methods}

The front is associated with a transition zone between two air or water masses of different density and temperature and is associated with significant changes in the weather and ocean. The thermal front is a meeting area of two water mass that has different sea surface temperature characteristics. The thermal front is an oceanographic phenomenon that affects the physical and biological conditions of waters. The meeting between the warm Java seawater mass and the cooler Indian Ocean water mass is an example of a potential thermal front area in Indonesian waters (Jatisworo \& Murdimanto, 2013; Podestá et al., 1993). The occurrence of the thermal front is often marked with the boundary of the process of raising the bottom water to the higher water which stimulated biological productivity called upwelling (Jing et al., 2016; Ohta et al., 2020).
Whereas, in meteorology, the term front defines the transition zone between two air masses of different density. Since temperature characteristics are the most important regulators of atmospheric density, a front accordingly separates air masses of different temperatures (American Meteorological Society, 2012). The front is similar to each other. However, the object is different, where the thermal front occurs on the sea surface, and the weather front occurs in the atmosphere

The area of study was focused in Bali Strait which located between $8^{\circ}-9^{\circ} \mathrm{S}$ and between $114^{\circ}-115^{\circ} \mathrm{E}$ (Fig. 1). Bali strait bounded by the Bali Sea in the north and the Indian Ocean in the south, the funnel-shaped face south towards the Indian Ocean causes these waters to be more affected by the mass of seawater from the Indian Ocean called South Equatorial Current (SEC) than the Indonesian Throughflow (ITF) entering from the north (Burhanuddin et al., 1984). ITF entering this strait with warm seawater while the Indian ocean brings colder water makes this region experienced thermal front almost throughout the year. Although this condition affected the oceanographic condition of South of East Java which experienced upwelling phenomena throughout the year, its condition most influenced by the ITF coming out from the Lombok Strait (Kuswardani \& Qiao, 2014; Valsala \& Maksyutov, 2010).

Bali Strait has oceanographic phenomena that are influenced by the annual season cycle, namely southeast and northwest monsoons. Southeast monsoon occurs in June September during northwest monsoon in December March. Moreover, El Niño-Southern Oscillation (ENSO) and Indian Ocean Dipole (IOD) interannual phenomena also affect these waters. Oceanographic condition and annual seasonal cycle in this region cause Bali Strait has an upwelling area that is a potential area for fishing activities almost throughout the year (Hendiarti et al., 2004).

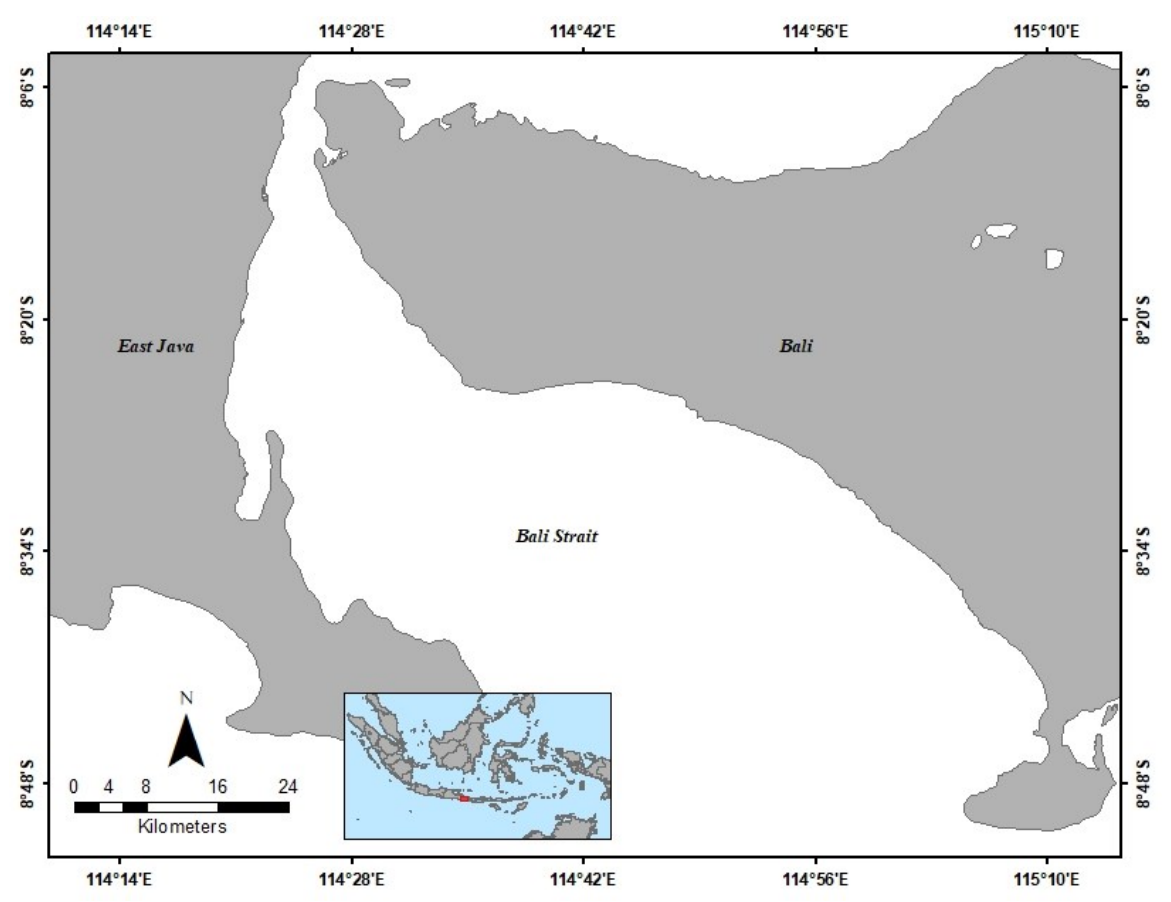

Figure 1. Study Area 
Sardinella is identical to the fishery products from the Bali Strait. Based on data from the Department of Maritime Affairs, Fisheries, and Forestry of Jembrana Regency, Bali, it was reported that the percentage of fish species most caught by Pengambengan fishermen in the 2007-2014 period was Sardinella (Sardinella lemuru) of $83.68 \%$ (Pertami et al., 2020). Sardinella fishing in the Bali Strait is one of the main small pelagic fisheries in Indonesia. This fishery is particular because it exploits a single species and is concentrated in a relatively narrow area.

The satellite data used in this study was Aqua MODIS (Moderate Resolution Imaging Spectroradiometer) satellite data. This data was obtained from GEE by open access. As a cloud computing infrastructure, GEE can provide a platform for multitemporal satellite data analysis from medium to high spatial resolution and satellite data itself. Earth Engine documents satellite imagery and stores it in public data archives that are updated daily and available for global-scale data mining. This study used sea-level temperature (SST) data from daily Aqua MODIS with a spatial resolution of 500 meters. The data period used was one year in 2016, which was then composited into monthly data. Daily data selection was used to identify real thermal front phenomena that occur every day and compare them with Bali Sardinella fishing zones which available in daily data. Although to analyze monthly phenomena, monthly composite data is also used.

Bali Sardinella fishing in 2016 occurred throughout the year and was proved by the available data of vessel number that caught fish, and total catch landed data. These data were available on logbooks submitted in the National Fishing Port of Pengambengan, Jembrana Bali, in 2016. Generally, the Indonesian fishing logbook contains daily information about the name of the vessel, type of fishing gear, the port of departure, fishing grounds, fishing points, composition and quantity of catch, etc. (Republik Indonesia, 2014). This study only used fishing points (the points for setting the fishing gear, given in longitude and latitude) and total catch landed data which available 1056 data of fishing coordinate in 139 days of fishing.

There are three general possibilities algorithms to automatically detect fronts in sea surface temperature data derived by satellite, namely gradient algorithm, histogram algorithm, and entropy algorithm (Chang \& Cornillon, 2015; Kirches et al., 2016). Gradient algorithm exploits spatial gradients within a sea surface temperature image, and histogram algorithm detects fronts on the frequency distribution of the values within image subsets while entropy algorithm is based on the difference calculated for each position above the image and reaches a maximum value when each sub-window lies entirely in one texture (Chang \& Cornillon, 2015; Shimada et al., 2005). The strength of histogram algorithm compared to other is the ability to detect weak fronts in the presence of high background noise so that algorithm is appropriate to apply in Indonesian waters where the difference of sea surface temperature anomaly is not significant (J. F. Cayula \& Cornillon, 1992; Kusuma et al., 2017; Ullman \& Cornillon, 2000). Familiar and good results histogram algorithm is Single Image Edge Detection (SIED) by J. F. Cayula \& Cornillon (1992) to detect thermal front in SST satellite images based on the histogram algorithm which works on the frequency distribution of the values within image subsets and has included cloud removal. This algorithm operated in 3 levels: picture level, window level, and local level. The picture level determines the probability area influenced by clouds. Window level determines statistics for SST front probability in all windows. Then, the local level determines edge pixel statistics by considering neighbouring pixels. SIED algorithm has implemented in LAPAN'S PFZ information because of his capability to detect thermal front in Indonesian waters. On the other hand, the information needs to validate accurate information about fishing areas.

The flowchart used in this study is attached in Figure 2. It contains two components: thermal front identification and analysis of the relation between the thermal front and Bali Sardinella fishing areas. Thermal front generated using SST Aqua MODIS imagery with Single Image Edge Detection (SIED) algorithm by J. F. Cayula \& Cornillon (1992).

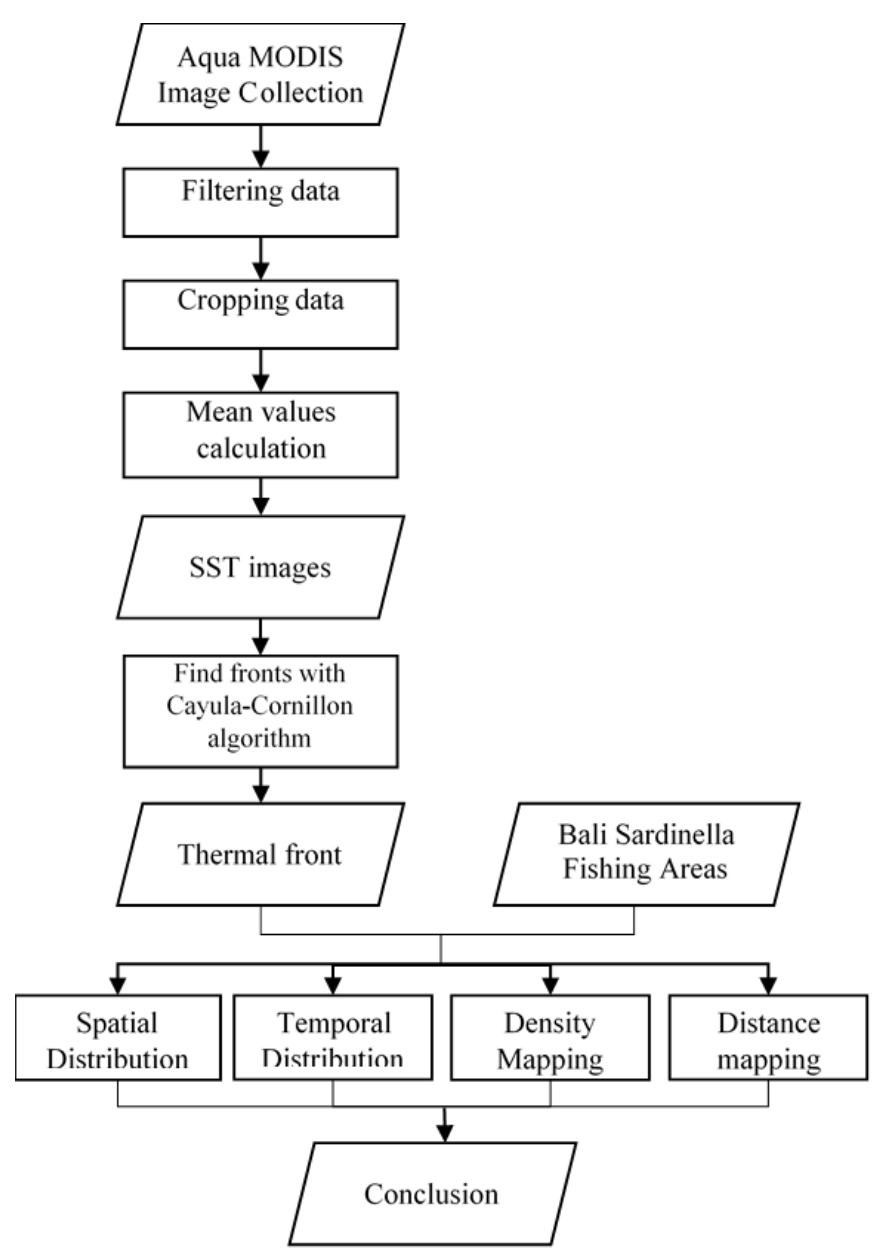

Figure 2. Flowchart of study to determine the relationship

between thermal front and Bali sardinella fishing areas.

Sea Surface Temperature data obtained from the Google Earth Engine platform (in level 3 product), and has applied to the cloud masking process. The data is collected in Ocean Color SMI: Standard Mapped Image MODIS Aqua Data includes a band of chlorophyll-a, fluorescence, mainly organic carbon and remote sensing reflectance so that this dataset potentially used to study biology and hydrology of coastal zones, coastal and marine diversity, biogeochemical fluxes until the impact of climate and environmental variability and changes in marine ecosystems.

The preprocessing step includes data preparing, filtering data, and cropping data with the area of interest (AOI). Spectral band selection is needed to match the purpose of the 
analysis, while Aqua MODIS has almost twenty bands. The needed band to analyze thermal front is an infrared band which is to form sea surface temperature. This Google Earth Engine provides this data collection where radiometric, geometric correction and cloud masking has been applied. 1056 coordinate of fishing effort available in the fishing logbook in 2016 and divided in 139 days. As the consequences of optical sensor Aqua MODIS, cloud cover in the tropical area is very high so results limited data of sea surface temperature that match with daily data of catchment data so that in the study area is available 101 daily data from 139 days of Bali Sardinella fishing data coordinate in 2016. SST data that has been meant calculated in GEE to perform SIED analysis in ArcMap to generate thermal front information.

To detect the thermal front in ArcMap, Marine Geospatial Ecology Tool (MGET) toolbox was applied to this study. It is an open-source geoprocessing ArcGIS toolbox designed to analyze ecology, oceanographic data research, and spatial problems (Roberts, 2010). This toolbox has implemented SIED algorithm by J. F. Cayula \& Cornillon (1992) in its toolbox to identify fronts in ArcGIS raster or binary files. The thermal front cannot be directly identified with MGET tools. There are several steps needed: extract by mask/AOI, convert decimal number to an integer, eliminate cloud/noise values, and resampling data. Extract by mask used to extracts the cells of a raster that correspond to the areas defined by a mask, integer number format needed to operate in ArcGIS software, preprocessed data still included noise value that influenced by the cloud so removal value in more than 35 and less than 19 is needed, and resampling data step used to change the spatial resolution the raster images for aggregating or interpolating values across the spatial resolution of Aqua MODIS satellite.
The daily fishing distribution is analyzed monthly in a year and correlates its information and thermal front information to the Monsoon season. Furthermore, Spatiotemporal analysis is done by analyzing distance of the fishing area to the nearest thermal front analysis to get the relationship between these parameters and supported by density mapping of thermal front and Bali sardinella fishing areas.

\section{Result and Discussion}

Thermal front detected using sea surface temperature (SST) data. In this case, we used SST data from Aqua MODIS imagery based on Bali Sardinella fishing logbook availability daily. Figure 4. shows SST distribution monthly in 2018, where the variability of SST has a significant influence based on monsoon variability. Indonesia has southeast monsoon which influenced SST in Bali strait to be cooler while the northwest makes the waters to be warmer. Throughout the year, Bali strait has SST between the south and east sides. The south side tends to be cooler while the north side tends to warmer. The southern water of Java to the western part of the Timor Sea is affected by the water mass from the Pacific Ocean which entering through Indonesian waters and influences the temperature of surface waters, this water mass called Indonesian Throughflow (ITF) (Bray et al., 1996; Gordon, 2005). ITF enter this area and meet with South Equatorial Current (SEC) as part of the Indian Ocean gyre which formed in the North West Coast of Australia and moved from Sumbawa to along the south coast of East Java include Bali strait (Setiawan et al., 2013; Wyrtki, 1961). SEC carries cold water mass in the Bali strait and meets with warmer water ITF, so that causes the appearance of thermal front throughout the season.
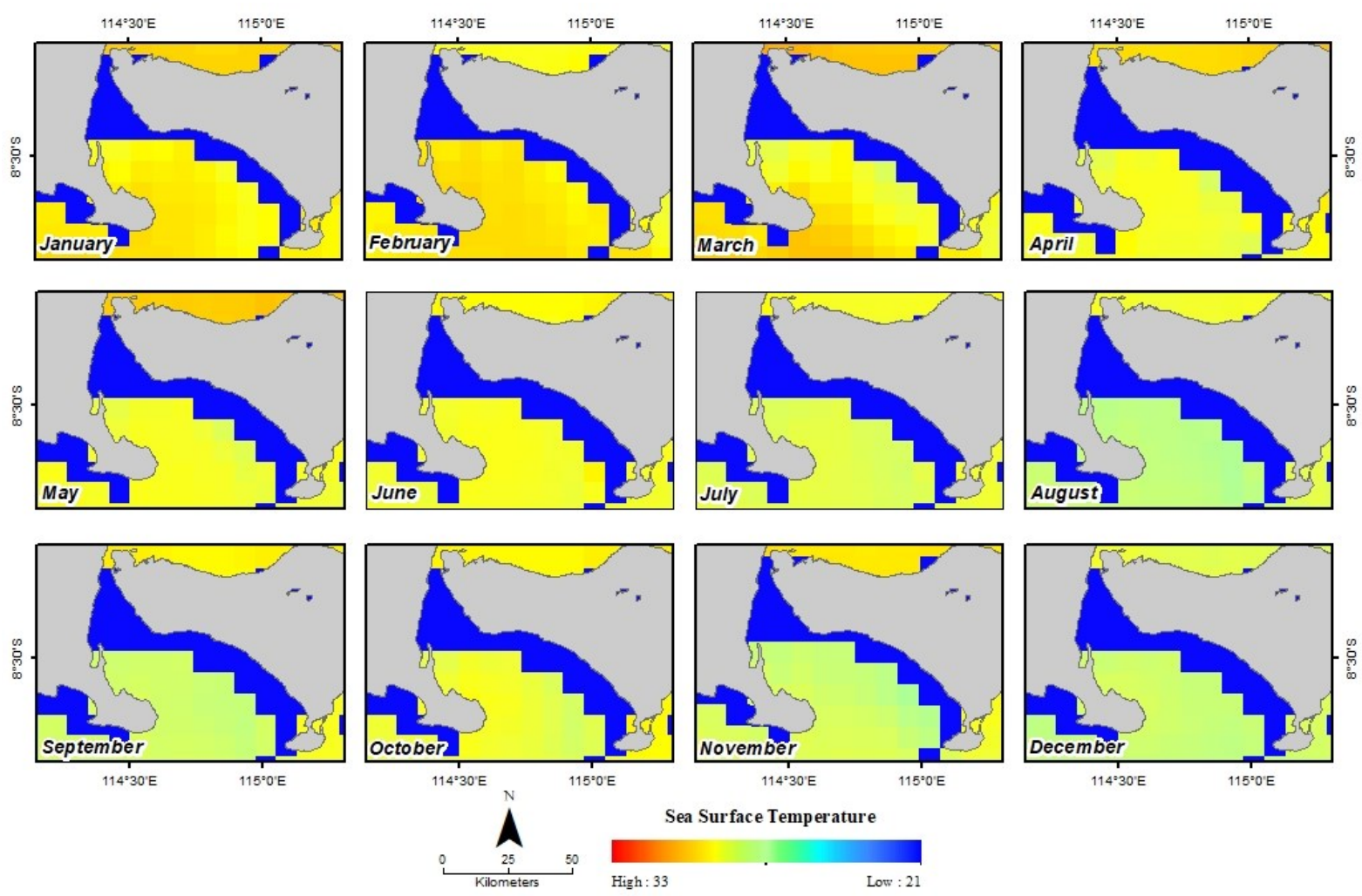

Sea Surface Temperature

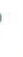

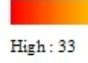

Figure 3. Sea surface temperature spatial distribution on Bali Strait 
The thermal front is the assembly area of two water masses which have a different surface temperature. In figure 5. the thermal front distribution transversely in SST distribution seem a significant temperature difference between two pixels. The red line showed the thermal front location, whereas the black showed a sample of transverse thermal profile while the grey showed land area. In the profile graph, it appears $0.85^{\circ} \mathrm{C}$ temperature difference which is the results of the threshold used $\left(0.5^{\circ} \mathrm{C}\right)$ so that the SIED algorithm can detect thermal front in this area. $0.5^{\circ} \mathrm{C}$ was the appropriate threshold to be used to detect the thermal front in Indonesian waters (Hamzah et al., 2014; Hanintyo et al., 2015; Jatisworo \& Murdimanto, 2013).

Thermal front distribution in Bali strait (Fig. 5 and 6) has different variations every month. These variations caused by the seasonal effect in Indonesia. The number of thermal fronts (TF) events shows a daily TF mosaic in a month. In general, detected TF would appear as blue but if at the same location occurs more than once in a month will change in a different colour, twice in a month are yellow, three times are green and purple four times. In this case, 2018 months produce a maximum of 4-time thermal front events that are in April and September while December and February did not have thermal front. Thermal front distribution during 2018 is more concentrated in the Bali strait which leads to the Java Sea and closes to the mainland in the bay. Moreover, the thermal front near the Indian Ocean is more minimal.

In this study, the daily thermal front was detected based on the daily Bali Sardinella fishing effort and is calculated monthly so that the total data of each month is different. A total of 1056 data of fishing effort coordinates is available in 139 data days, from 139 daily fishing effort data filtered based on Aqua MODIS data availability which has cloud cover less than $50 \%$ to obtain thermal front information that have the same day as fishing effort.
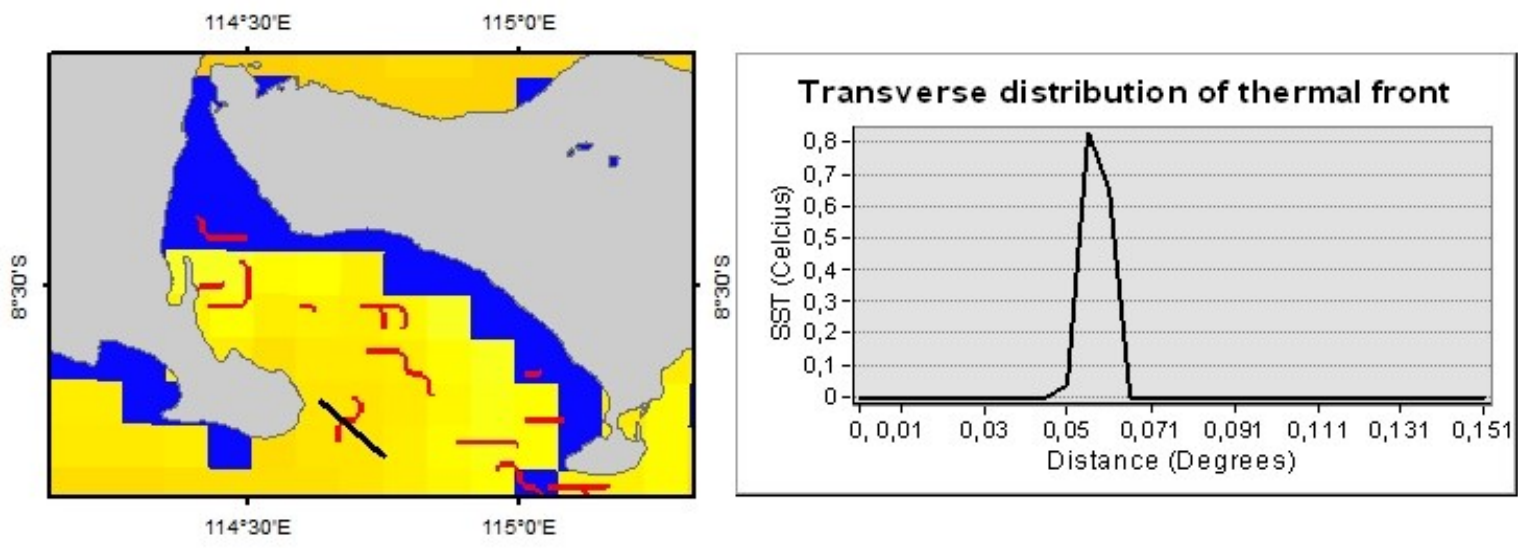

Figure 4. The thermal front profile a.) The thermal front transverse profile in SST (black line)

b.) Transverse distribution of thermal front in graph a.
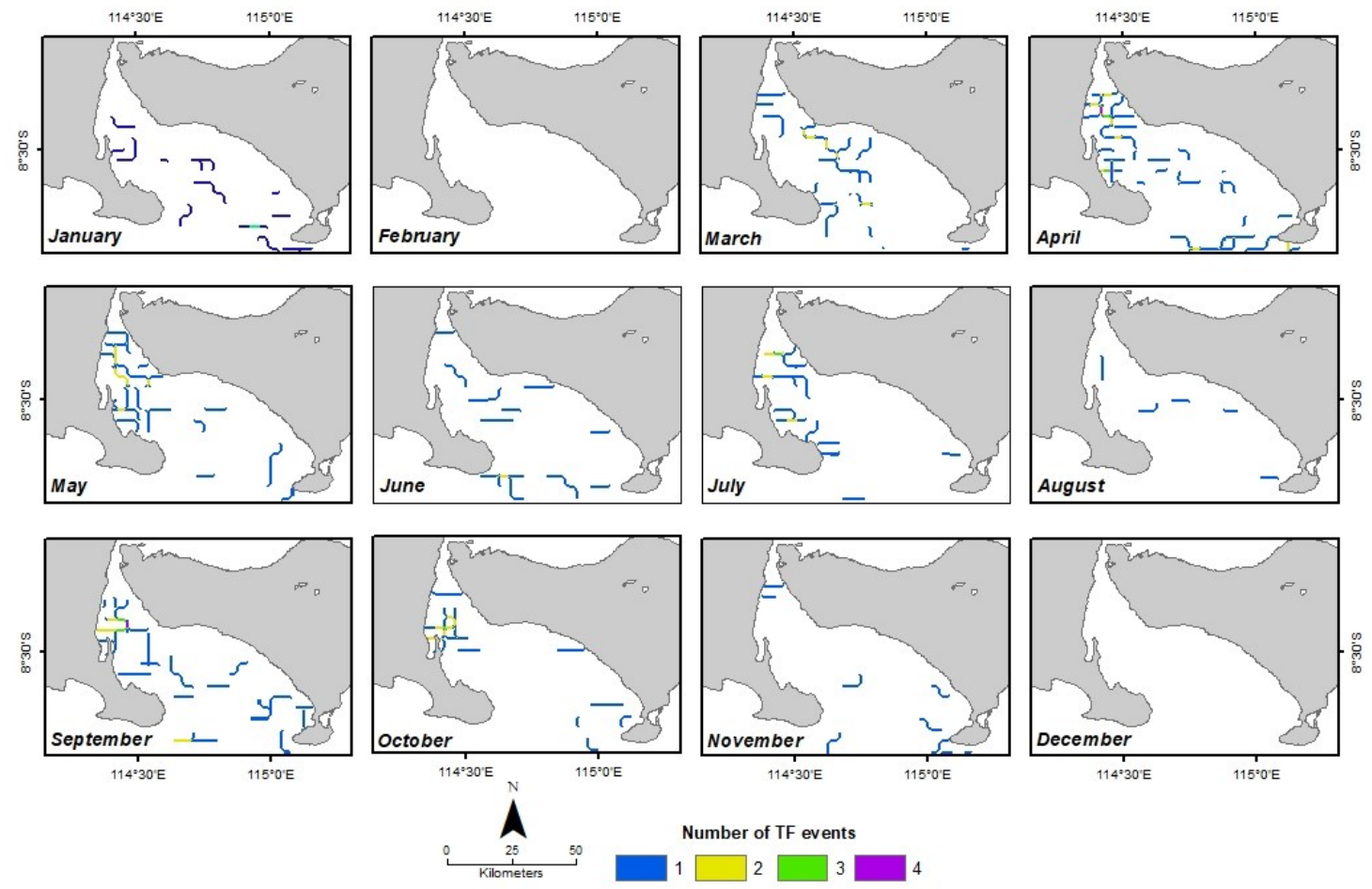

Figure 5. Thermal front spatial distribution on Bali Strait. 


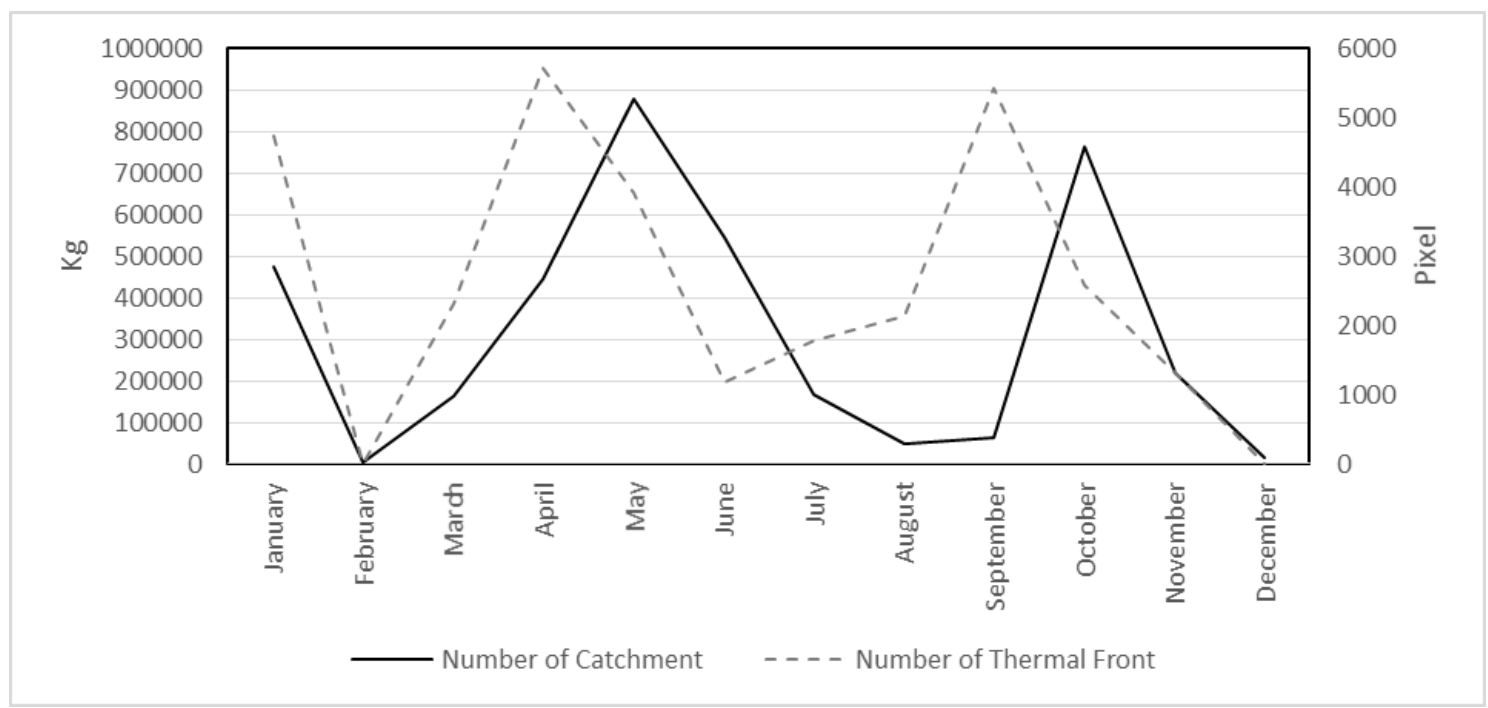

Figure 6. Temporal distribution of Thermal front and number of fishing.

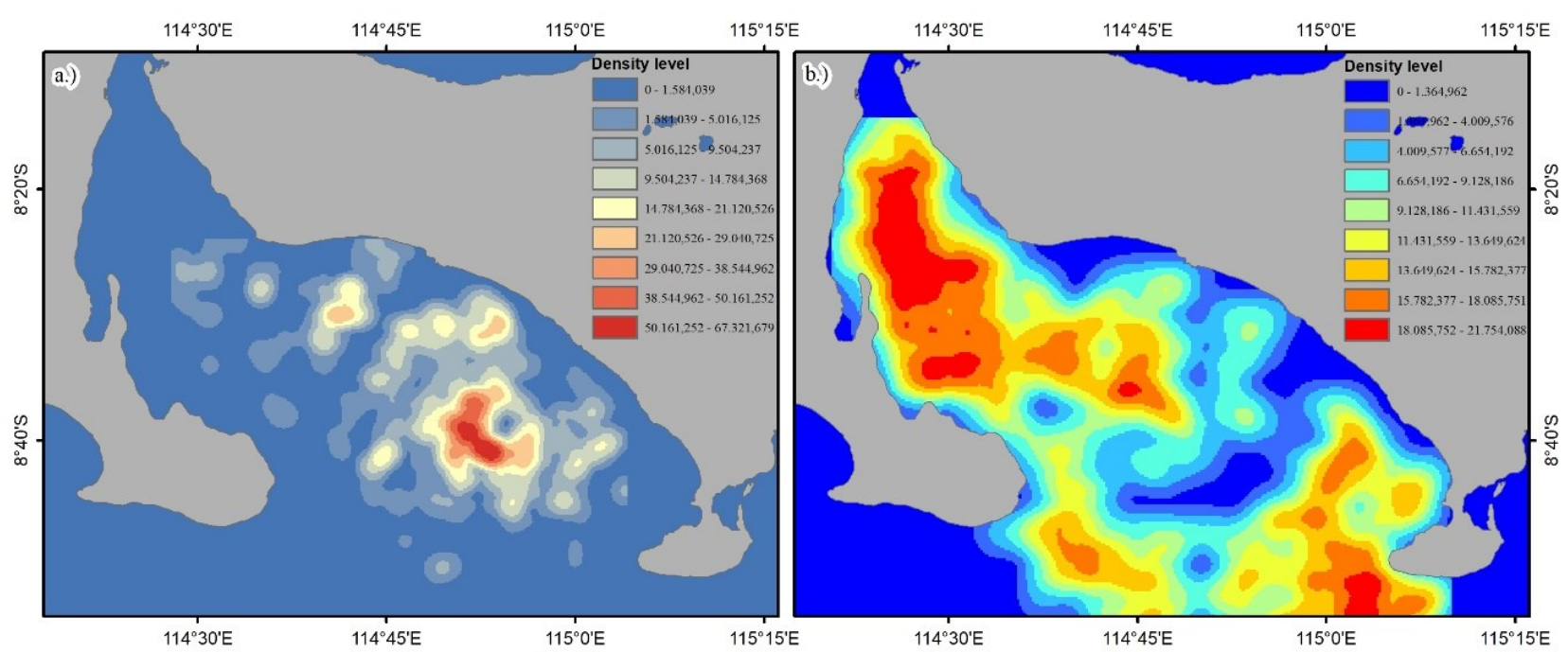

Figure 7. a) Bali sardinella fishing area density b) Thermal front distribution density.

Figure 8. shows the temporal distribution between the number of thermal front and fishing. Blackline indicates the number of fishing and the dotted line for the number of the thermal front. Thermal front, maximum values reached in April and September, while fishing values were maximum in May. Fishing effort in February and December were minimum values causing the graphic to drop to down. This phenomenon can be related to weather conditions in the season where the west season rainfall and sea waves will be high, causing a decrease in the amount of fishing effort. Based on Wyrtki (1961), during the northwest monsoon, the rainfall will be high, and many rivers will go to the sea, causing a temperature difference around the land.

The number of thermal fronts counted by pixel values from identification where every pixel has a 500 square meter area. At the peak time, the thermal front reached 5712 pixels while in February and December thermal front was not identified. In 2018, Bali sardinella had maximum fishing values in May, which is $879.626 \mathrm{~kg}$. The number of the fishing graphic is directly proportional to thermal front values but has delay time, e.g. April is a peak time of thermal front, and May is the peak time of Bali sardinella fishing.

Density toolset was applied to calculate magnitude per unit area from point each point of Bali sardinella fishing areas and thermal front. The result of density calculation can define the spreading values of each input over the surface. Figure 8. shows all density identified from daily data during 2016. The red area in figure 8 . indicates high frontal densities, yellow indicates medium and blue for low density. The thermal front has a high frontal density on the Bali strait which is directly adjacent to the Java sea and Lombok strait. Moreover, the Bali sardinella fishing area has a high density in the center of Bali strait and not near the land.

Although we have used the same class in determining density classification, there is no significant association between Bali sardinella fishing areas and thermal front density. Most of the fishing effort is made in a location that has a minimum thermal front event. Possible cause is the location of the thermal front with a high density near the inter-island crossing area. 
To analyze the suitability of the phenomena between Bali sardinella fishing areas to the thermal front, point matching analysis was applied among one another in the same period. However, in this context, there was no significant matching found among them. In the 101 processed data, only 3 locations found which have spatial matching point among the variables.

No appearance has a significant association among the phenomenon; hence the accuracy was tested by measuring the distance among the variables. The distance measured with the proximity of position between the coordinates of Bali sardinella fishing areas and nearest thermal front occurrence within a radius $3,3,10$, and $20 \mathrm{~km}$ as a spatial analysis boundary. $3,3 \mathrm{~km}$ was taken from the accurate distance information in the LAPAN PFZ. 10, and $20 \mathrm{~km}$ distance was based on the length of the fishing net used by several fishing ships in Bali strait. Besides, to the accuracy percentage of the fishing area position, information accuracy was also measured based on the suitability of the information of the thermal front with the fishing effort.

Table 1. shows the amount of distance matching used to measure the proximity of fishing areas and thermal front. Based on the analysis results, a $3.3 \mathrm{~km}$ radius of the LAPAN PFZ accuracy cannot represent the best distance in measuring the position of the thermal front with the Bali sardinella fishing area. The suitable point will increase with increasing buffer distance used. The maximum distance used to show 36 matching points from 101 data compared or at range $35,6 \%$. Not only the percentage of a matching number but also the monthly distribution did not show a significant association between these two variables. Figure 9. illustrates scatterplot from matching number analysis where the highest number of matching points was obtained at 6 points, namely in April and September while February and December did not have any matching point.

Table 1. Matching distance between Bali Sardinella fishing areas and thermal front

\begin{tabular}{lllll}
\hline Months & Point match & $3.3 \mathrm{~km}$ match & $10 \mathrm{~km}$ match & $20 \mathrm{~km}$ match \\
\hline January & 1 & 1 & 2 & 2 \\
February & 0 & 0 & 0 & 0 \\
March & 1 & 1 & 2 & 2 \\
April & 0 & 1 & 4 & 6 \\
May & 0 & 1 & 2 & 5 \\
June & 0 & 1 & 2 & 5 \\
July & 0 & 1 & 1 & 2 \\
August & 0 & 0 & 1 & 3 \\
September & 1 & 2 & 3 & 6 \\
October & 0 & 1 & 2 & 3 \\
November & 0 & 0 & 2 & 2 \\
December & 0 & 0 & 0 & 0 \\
Total & 3 & 9 & 21 & 36 \\
\hline
\end{tabular}

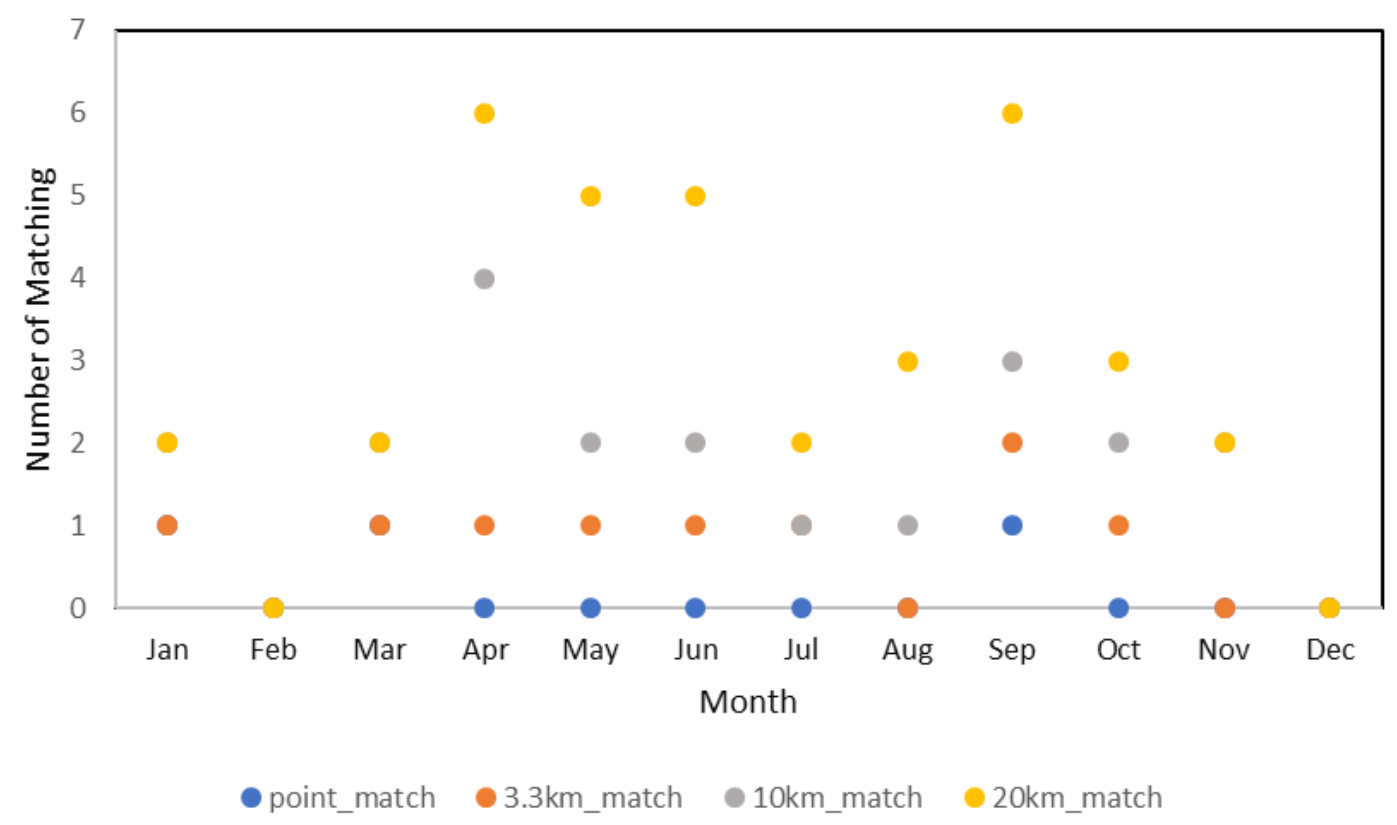

Figure 8. Scatterplot of matching number between Bali sardinella fishing area and thermal front. 
This paper is to examine the hypothesis that the thermal front indicates the location of fish so that we measure how strong the association. The hypothesis is strongly debated after the matching point from the variables are shown. We used three methods to analyze this argument that is (1.) spatial distribution, (2.) temporal distribution, (3.) density, and (4.) matching distance. The results show thermal front location is concentrated in the Bali strait, which is adjacent to the Java Sea and Indian ocean. Not like the thermal front, Bali sardinella fishing areas are concentrated around Bali strait. Bali sardinella fishing areas may be influenced by vessel size. However, the vessel size used is from 6 until 29 gross ton (GT).

The thermal front was predominantly found in the peak of first (April) and second (September) transitional season, which was the peak season for the thermal front to occur in a year. The least of the thermal front occurred in the Southwest monsoon. According to Susilo, 2015, salinity measurement results in the Bali Strait during the period April-October showed that salinity in April-June and September tends to be lower. The low salinity intensity in the Flores and surrounding waters is due to the mass flow of water from the Java Sea, which partially entered the Bali Strait (Susilo, 2015; Wyrtki, 1961). Salinity has an inverse relationship with temperature. A minimum salinity value will follow the maximum temperature value. Variation and interaction between temperature and salinity determine the density of seawater, which affects the vertical motion of seawater mass. Fish tend to choose areas with salinity levels that correspond to their respective osmotic pressures (Susilo, 2015). Even though the thermal front can indicate the potential fishing ground or schooling fish point, another sea environment parameter in the field can also contribute to the peak of Sardinella catchment. The peak of fishing results in April indicates that the movement of the number of thermal fronts increased significantly from March to the peak point in May has created fishing grounds for fishers over the period. It can be assumed that before reaching the peak of the number of thermal fronts, the number of Sardinella has decreased.

Matching point analyzes results $20 \mathrm{~km}$ is the best distance to measure the thermal front and Bali sardinella association, where the result shows about 35,6\% matched. This matched result indicates their associations are less significant in these waters. Three possibilities are causing these results: thermal front is not the main parameter that can predict Bali sardinella location, the thermal front takes time for the eating cycle, so Bali Sardinella is at that location, the fisherman does not determine the location of Bali sardinella based on thermal front location. This possibility is based on the fact that fishermen in the area still use traditional methods in determining the fishing area that is from experience found fish. Future studies are expected to find an association between the Bali sardinella fishing areas and the habitat parameters of the fish (thermal front and chlorophyll-a).

\section{Conclusion}

The association between the thermal front and Bali sardinella fishing areas has been presented in this paper. The thermal front in the Bali strait can be identified using the SIED algorithm with $0.5^{\circ} \mathrm{C}$ SST as a threshold. The thermal front has fairly even distribution in Bali strait however strong density of thermal front only found in Bali strait water which is adjacent with Java sea and Indian ocean. Bali strait is an area that has an abundance of Bali sardinella. The association between thermal front and Bali sardinella is more significant in $20 \mathrm{~km}$ buffering areas. However, a $35.6 \%$ matching point can be described that the thermal front parameter has a role to predict the fish location, even though the correlation is still not significantly found yet in the same period where there is a time delay in peak of each parameter.

\section{Acknowledgement}

This research was funded by the budget of DIPA LAPAN activities in 2019, Remote Sensing Application Center, Indonesian National Institute of Aeronautics and Space (LAPAN). Thanks for going to RSAC LAPAN, which has supported the implementation of this research. Aqua MODIS images were provided by NASA Goddard Space Flight Center, Ocean Ecology Laboratory, Ocean Biology Processing Group in Google Earth Engine. Both authors are the main contributor to this paper.

\section{References}

American Meteorological Society Glossary of Meteorology: Front (2012). Available at: http://glossary.ametsoc.org/wiki/Fronts, last access: 8 July 2020.

Burhanuddin, M. H., Martosewojo, S., \& Moeljanto, R. (1984). Sumberdaya Ikan Lemuru. Proyek Studi Sumber Daya Alam Indonesia. Studi Potensi Sumber Daya Hayati Ikan. Lembaga Oseanografi Nasional-LIPI. Jakarta, 70.

Bray, N. A., Hautala, S., Chong, J., \& Pariwono, J. (1996). Largescale sea level, thermocline, and wind variations in the Indonesian throughflow region. Journal of Geophysical Research C: Oceans, 101(C5), 12239-12254. https:// doi.org/10.1029/96JC00080.

Cayula, J.-F., \& Cornillon, P. (1995). Multi-Image Edge Detection for SST Images. In Journal of Atmospheric and Oceanic Technology (Vol. 12, Issue 4, pp. 821-829). https:// doi.org/10.1175/1520-0426(1995)012<0821:miedfs $>2.0 . c 0 ; 2$.

Cayula, J. F., \& Cornillon, P. (1992). Edge detection algorithm for SST images. Journal of Atmospheric \& Oceanic Technology, 9(1), 67-80. https://doi.org/10.1175/1520-0426(1992) $009<0067$ :EDAFSI $>2.0$.CO;2.

Chang, Y., \& Cornillon, P. (2015). A comparison of satellite-derived sea surface temperature fronts using two edge detection algorithms. Deep-Sea Research Part II: Topical Studies in Oceanography, 119, 40-47. https://doi.org/10.1016/ j.dsr2.2013.12.001.

FAO. (2001). FAO Species Identification Guide for Fishery Purposes. The Living Marine Resources of Thr Western Central Pacific, 1, 2831-2836.

Gordon, A. L. (2005). Oceanography of the Indonesian seas and their throughflow. Oceanography, 18(SPL.ISS. 4), 15-27. https://doi.org/10.5670/oceanog.2005.01.

Hamzah, R., Prayogo, T., \& Harsanugraha, W. K. (2014). Identifikasi Thermal Front dari Data satelit Terra / Aqua MODIS Menggunakan Metode Single Image Edge Detection ( SIED )( Studi Kasus $\bowtie$ : Perairan Utara dan Selatan Pulau Jawa).

Hamzah, R., Prayogo, T., \& Marpaung, S. (2016). Metode Penentuan Titik Koordinat Zona Potensi Penangkapan Ikan Pelagis Berdasarkan Hasil Deteksi Termal Front Suhu Permukaan Laut.

Hanintyo, R., Hadianti, S., Mahardhika, R. M. P., \& Aldino, J. S. (2015). Sebaran Musiman Kejadian Thermal Front Berdasarkan Citra Aqua-. 523-635.

Hendiarti, N., Siegel, H., \& Ohde, T. (2004). Investigation of different coastal processes in Indonesian waters using 
SeaWiFS data. Deep-Sea Research Part II: Topical Studies in Oceanography, 51(1-3), 85-97. https://doi.org/10.1016/ j.dsr2.2003.10.003

Jatisworo, D., \& Murdimanto, A. (2013). Identifikasi thermal front di Selat Makassar dan Laut Banda. Simposium Nasional Sains Geoinformasi III, 1962, 226-232.

Jing, Z., Qi, Y., Fox-Kemper, B., Du, Y., \& Lian, S. (2016). Seasonal thermal fronts on the northern South China Sea shelf: Satellite measurements and three repeated field surveys. Journal of Geophysical Research: Oceans, 121(3), 1914-1930. https://doi.org/10.1002/2015JC011222.

Kirches, G., Paperin, M., Klein, H., Brockmann, C., \& Stelzer, K. (2016). Remote Sensing of Environment GRADHIST - A method for detection and analysis of oceanic fronts from remote sensing data. Remote Sensing of Environment, 181, 264-280. https://doi.org/10.1016/j.rse.2016.04.009.

Kusuma, D. W., Murdimanto, A., Aden, L. Y., Sukresno, B., Jatisworo, D., \& Hanintyo, R. (2017). Sea Surface Temperature Dynamics in Indonesia. IOP Conference Series: Earth and Environmental Science, 98(1). https:// doi.org/10.1088/1755-1315/98/1/012038.

Kuswardani, R. T. D., \& Qiao, F. (2014). Influence of the Indonesian Throughflow on the upwelling off the east coast of South Java. Chinese Science Bulletin, 59(33), 4516-4523. https:// doi.org/10.1007/s11434-014-0549-2.

Ohta, J., Yasukawa, K., Nozaki, T., Takaya, Y., Mimura, K., Fujinaga, K., Nakamura, K., Usui, Y., Kimura, J. I., Chang, Q., \& Kato, Y. (2020). Fish proliferation and rare-earth deposition by topographically induced upwelling at the late Eocene cooling event. Scientific Reports, 10(1), 3-4. https:// doi.org/10.1038/s41598-020-66835-8

Pertami, N. D., Rahardjo, M. F., Damar, A., Nurjaya, I. W., Kelautan, F., Udayana, U., Raya, J., Unud, K., Jimbaran, B., Dramaga, K. I. P. B., \& Agatis, J. (2020). ( Lemuru fish, the belle of the disappearing Bali Strait fisheries ) Bali.4(April), 1 -7 .

Pet, J. S., Van Densen, W. L. T., Machiels, M. A. M., Sukkel, M., Setyohadi, D., \& Tumuljadi, A. (1997). Catch, effort and sampling strategies in the highly variable sardine fisheries around East Java, Indonesia. Fisheries Research, 31(1-2),
121-137. https://doi.org/10.1016/S0165-7836(97)00007-6.

Podestá, G. P., Browder, J. A., \& Hoey, J. J. (1993). Exploring the association between swordfish catch rates and thermal fronts on U.S. longline grounds in the western North Atlantic. Continental Shelf Research, 13(2-3), 253-277. https:// doi.org/10.1016/0278-4343(93)90109-B.

Republik Indonesia, M. K. dan P. (2014). Peraturan Menteri Kelautan dan Perikanan Republik Indonesia No.18/ PERMEN-KP/2014 Tentang Wilayah Pengelolaan Perikanan Negara Republi Indonesia. Peraturan Menteri.

Robinson, I. (2006). Chapter 6 SATELLITE MEASUREMENTS FOR OPERATIONAL OCEAN MODELS. 147-189.

Setiawan, A. N., Dhahiyat, Y., \& Purba, N. P. (2013). Variasi sebaran suhu dan klorofil-a akibat pengaruh Arlindo terhadap distribusi ikan cakalang di Selat Lombok Variation of temperature and chlorophyll-a due toIndonesian throughflow on skipjack distribution in Lombok Strait. 2(2), 58-69.

Shimada, T., Sakaida, F., Kawamura, H., \& Okumura, T. (2005). Application of an edge detection method to satellite images for distinguishing sea surface temperature fronts near the Japanese coast. 98, 21-34. https://doi.org/10.1016/ j.rse.2005.05.018

Susilo, E. (2015). Variabilitas Faktor Lingkungan Pada Habitat Ikan Lemuru Di Selat Bali Menggunakan Data Satelit Oseanografi Dan Pengukuran Insitu. Omni-Akuatika, 14(20), 13-22.

Ullman, D. S., \& Cornillon, P. (2000). Evaluation of Front Detection Methods for Satellite-Derived SST Data Using In Situ Observations Evaluation of Front Detection Methods for Satellite-Derived SST Data Using In Situ Observations. December.

Valsala, V., \& Maksyutov, S. (2010). A Short Surface Pathway of the Subsurface Indonesian Throughflow Water from the Java Coast Associated with Upwelling, Ekman Transport, and Subduction. International Journal of Oceanography, 2010 (1), 1-15. https://doi.org/10.1155/2010/540783.

Wyrtki, K. (1961). NAGA REPORT Volume 2 Scientific Results. 195. https://doi.org/10.1001/archneur.1994.00540230067015. 